\title{
Reassessment of the potential economic impact of cattle parasites in Brazil
}

Reavaliação do potencial impacto econômico de parasitos de bovinos no Brasil

Laerte Grisi ${ }^{1 *}$; Romário Cerqueira Leite²; João Ricardo de Souza Martins ${ }^{3}$; Antonio Thadeu Medeiros de Barros ${ }^{4}$; Renato Andreotti ${ }^{4}$; Paulo Henrique Duarte Cançado ${ }^{4}$; Adalberto Angel Pérez de León ${ }^{5}$; Jairo Barros Pereira ${ }^{6}$; Humberto Silva Villela ${ }^{6}$

${ }^{1}$ Universidade Federal Rural do Rio de Janeiro - UFRRJ, Seropédica, RJ, Brasil

${ }^{2}$ Universidade Federal de Minas Gerais - UFMG, Belo Horizonte, MG, Brasil

${ }^{3}$ Instituto de Pesquisas Veterinárias Desidério Finamor, Fundação Estadual de Pesquisa Agropecuária - FEPAGRO, Eldorado do Sul, RS, Brasil

${ }^{4}$ Embrapa Gado de Corte, Campo Grande, MS, Brasil

${ }^{5}$ USDA-ARS Knipling-Bushland U.S. Livestock Insects Research Laboratory, Kerrville, TX, USA

USDA is an equal opportunity provider and employer

${ }^{6}$ Champion Farmoquímico Ltda, Anápolis, GO, Brasil

Received November 6, 2013

Accepted March 19, 2014

\begin{abstract}
The profitability of livestock activities can be diminished significantly by the effects of parasites. Economic losses caused by cattle parasites in Brazil were estimated on an annual basis, considering the total number of animals at risk and the potential detrimental effects of parasitism on cattle productivity. Estimates in U.S. dollars (USD) were based on reported yield losses among untreated animals and reflected some of the effects of parasitic diseases. Relevant parasites that affect cattle productivity in Brazil, and their economic impact in USD billions include: gastrointestinal nematodes - \$7.11; cattle tick (Rhipicephalus (Boophilus) microplus) - \$3.24; horn fly (Haematobia irritans) - \$2.56; cattle grub (Dermatobia hominis) - \$0.38; New World screwworm fly (Cochliomyia hominivorax) - \$0.34; and stable fly (Stomoxys calcitrans) - \$0.34. The combined annual economic loss due to internal and external parasites of cattle in Brazil considered here was estimated to be at least USD 13.96 billion. These findings are discussed in the context of methodologies and research that are required in order to improve the accuracy of these economic impact assessments. This information needs to be taken into consideration when developing sustainable policies for mitigating the impact of parasitism on the profitability of Brazilian cattle producers.
\end{abstract}

Keywords: Cattle parasites, production loss, economic assessment.

\section{Resumo}

A rentabilidade da atividade pecuária pode ser diminuída significativamente pelos efeitos dos parasitos que afetam o gado. As perdas econômicas causadas pelos parasitos dos bovinos, no Brasil, foram estimadas em uma base anual, considerandose o número total de animais em risco e os efeitos negativos do parasitismo sobre a produtividade do gado. Estimativas em dólares baseiam-se em perdas de rendimento conhecidas em animais não tratados, e refletem alguns dos efeitos de doenças parasitárias. Aqui, tais perdas são referidas como perdas potenciais. Parasitos relevantes que afetam o bem-estar do gado e a produtividade no Brasil e seu impacto econômico em dólares incluem: nematódeos gastrintestinais - $\$ 7,11$ bilhóes; carrapato bovino (Rhipicephalus (Boophilus) microplus) - \$3,24 bilhöes; mosca-dos-chifres (Haematobia irritans) - \$2,56 bilhōes; berne (Dermatobia hominis) - \$0,38 bilhôes; mosca-da-bicheira (Cochliomyia hominivorax) - \$0,34 bilhôes; e a mosca-dos-estábulos (Stomoxys calcitrans) - \$0,34 bilhôes. A perda econômica anual combinada, devido aos parasitos internos e externos dos bovinos aqui listados, foi estimada em pelo menos $\$ 13,96$ bilhôes. Tais resultados são discutidos no contexto de metodologias e pesquisas necessárias, como a que envolve os efeitos da resistência aos parasiticidas de uso veterinário, para melhorar a precisão de tais avaliaçôes de impacto econômico. Essa informação deve ser considerada pelos tomadores de decisão para influenciar programas de investigação e regulaçáo, a fim de desenvolver políticas sustentáveis que reduzam o impacto do parasitismo sobre a rentabilidade dos pecuaristas brasileiros.

Palavras-chave: Parasitose bovina, perda na produção, danos por parasitos.

\footnotetext{
*Corresponding author: Laerte Grisi

Departamento de Parasitologia Animal, Instituto de Veterinária, Universidade

Federal Rural do Rio de Janeiro - UFRRJ, BR 465, Km 7, CEP 23890-000,

Seropédica, RJ, Brasil

e-mail: lgrisi@ufrrj.br
} 
In 2002, Grisi et al. made an attempt to assess the economic impact of cattle parasitism in Brazil. The resulting study was regarded as an important source of data on the economic drag that endo and ectoparasites inflict on cattle, especially from the producer's point of view. More than 10 years later, a lot has changed in the Brazilian livestock scenario: new data regarding production losses due to parasites have become available from many regions of the country. Hence, there was a need for an update.

Occurrences of internal and external parasites in cattle throughout Brazil are favored by the predominance of tropical and subtropical climates. The national cattle herd is estimated to comprise 212,797,824 heads, distributed over 8 million square kilometers of land (IBGE, 2011).

The economic impact of external parasites on cattle is mostly associated with infestations by the cattle tick, Rhipicephalus (Boophilus) microplus, horn fly (Haematobia irritans), cattle grub (Dermatobia hominis) and New World screwworm (Cochliomyia hominivorax). Furthermore, the importance of the stable fly (Stomoxys calcitrans) has increased over the last few years because of outbreaks associated with postharvest residues of the sugarcane industry (BARROS et al., 2010a). Other ectoparasites, such as the cattle mange and sucking and chewing lice, are seasonal and limited to the southern regions.

Drummond et al. (1981) estimated the annual losses due to cattle parasites to be $\$ 2,260$ million in the United States, not including the costs of parasite control. This figure represented 10\% of the value of production and sales at the time. The annual loss estimates for specific pests ranged from $\$ 29.7$ million for scabies and mange mites to $\$ 730.3$ million for horn flies. The cattle population in the USA in 1981 was estimated to be 124.7 million (NASS; USDA, 2011).

Grisi et al. (2002) estimated that the total economic losses due to ectoparasites in cattle in Brazil were $\$ 2,650$ million. At that time, economic losses relating to the most important ectoparasite, the cattle tick, were based in a previous estimate by Horn (1983) of $\$ 968$ million for a national cattle herd of 76 million head.

The potential economic losses due to cattle parasitism in Brazil caused by major ectoparasite species and gastrointestinal nematodes are evaluated here. Estimates of the potential economic losses of each parasite species or group are based on numbers of animals at risk and on the available data on losses in milk production and weight gain of beef cattle. Most of the data are from local studies; when such information is unavailable, estimates are based on selected studies conducted elsewhere. Because information regarding production losses was obtained from control animals (animals kept untreated in the respective studies), the resulting estimates of economic losses represent potential losses among untreated cattle. Thus, the estimates presented do not necessarily represent the actual impact of cattle parasitism in Brazil but the potential losses expected in the absence of parasite control measures.

The impact of gastrointestinal nematodes on cattle production has been extensively studied worldwide. Lima and Grisi (1984) assessed the milk production of cows medicated with albendazole at parturition in the state of Rio de Janeiro in comparison with controls, and reported an increase of $51.90 \mathrm{~kg}$ of milk per cow in the medicated group during the 90-day study period, which corresponded to $0.58 \mathrm{~kg}$ of milk/cow/day. Ploeger et al. (1989) conducted a similar study in Holland and reported an increase of $0.44 \mathrm{~kg}$ of milk/cow/day. Charlier et al. (2009) summarized the data prior to 1997 from studies on the impact of subclinical gastrointestinal parasitism in dairy cattle, and showed that medication produced an increase of 0.4 to $0.8 \mathrm{~kg}$ of milk/cow/day. Considering an average loss of $0.6 \mathrm{~kg}$ of milk per cow per day without medication, the potential losses of the dairy cattle population at risk due to gastrointestinal worms in Brazil would be $\$ 1,870.48$ million (Table 1 ).

Based on 6 years of field trials with weaned Nelore cattle on improved pastures in central-western Brazil, Bianchin et al. (1995) showed that there was a superior average weight gain of $41 \mathrm{~kg}$ when the animals were dewormed following a strategic program. Likewise, studies conducted by Pinheiro (1983) showed that there was a difference of $67 \mathrm{~kg}$ in weight gain per animal between treated and untreated groups in the southern region. Analysis on data relating to beef cattle yearlings and heifers up to 2 years old showed that the potential losses due to helminth parasitism amounted to $\$ 5,237.49$ million. Because of control problems commonly observed in the field, the potentially high losses due to gastrointestinal nematodes in dairy and beef cattle, estimated as $\$ 7,107.97$ million (Table 1 ), strongly suggest that this parasitism represents the most important economic problem due to parasites in the country.

The damage to milk production caused by cattle ticks was recently evaluated by Rodrigues and Leite (2013) in the state of Minas Gerais, where $24.2 \%$ of the country's dairy cows are concentrated. These authors estimated that ticks were responsible for a reduction of $90.24 \mathrm{~L}$ in milk production per cow per lactation, which, when extrapolated to the national dairy herd, amounted to about $\$ 922.36$ million of losses to the national dairy herd. Estimates of the losses inflicted by cattle tick on beef cattle were based on Jonsson (2006), who reported daily losses of 1.18 and 1.37 grams per tick per animal for Bos indicus $\mathrm{x}$ Bos taurus cattle and $B$. taurus, respectively. Average tick infestations were obtained from Smith et al. (2000) for B. taurus (94 ticks/animal) and Gomes et al. (1989) for B. indicus (3.3 ticks/animal) and crossbreeds (32 ticks/animal). Considering the whole Brazilian beef cattle herd (about 11\% B. taurus and 89\% B. indicus and crossbreeds), the potential economic losses caused by this tick on beef cattle were estimated to be $\$ 2,313.99$ million. Therefore, the total economic loss attributable to $R$. $(B)$ microplus in the Brazilian cattle herd may approach $\$ 3,236.35$ million (Table 2 ).

Losses due to horn fly infestation were based on the studies of Bianchin and Alves (2002) and Bianchin et al. (2004), which estimated average yearly weight losses of $3.25 \mathrm{~kg}$ per cow, $2.00 \mathrm{~kg}$ per calf and $12.19 \mathrm{~kg}$ per steer (value also used for heifers). Considering populations at risk, as well as current market values, the total losses due to horn fly parasitism in Brazil approach \$2,558.32 million (Table 3). Although infestations by the horn fly and the closely related buffalo fly ( $H$. irritans exigua) may reduce milk production (JONSSON; MAYER, 1999), the relatively low infestations usually observed on dairy cattle, probably due to frequent cattle tick treatments, suggest that the impact of horn flies may be not so evident in Brazil. No estimate of horn fly losses on dairy cattle or beef cattle pregnancy rates is provided here, since these subjects need further investigation. 
Table 1. Economic losses due to gastrointestinal nematodes among dairy and beef cattle in Brazil, in 2011.

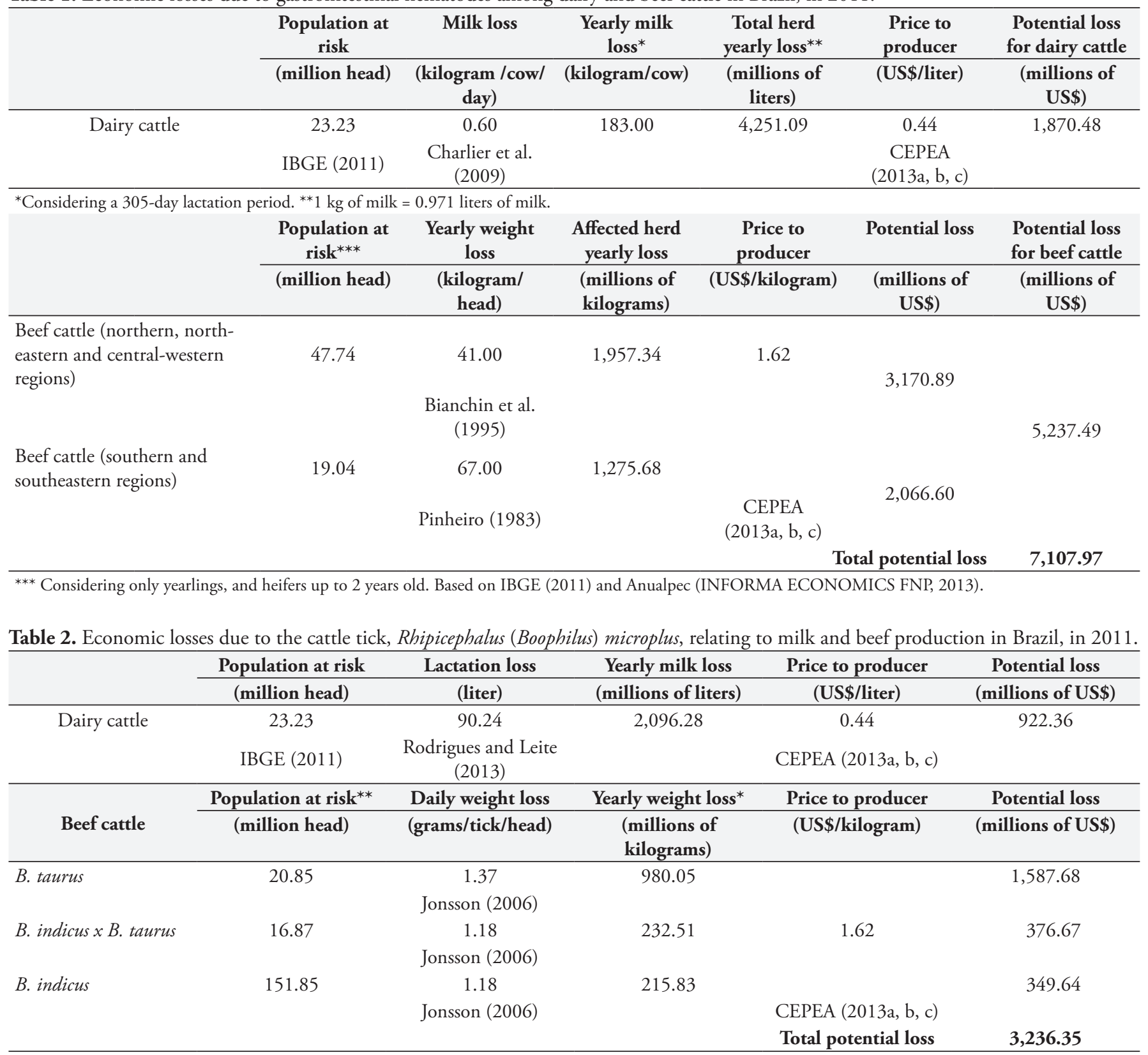

${ }^{*}$ Considering the following mean daily tick burdens: B. taurus - 94 ticks (SMITH et al., 2000), B. indicus $x$ B. taurus -32 ticks, and B. indicus - 3.3 ticks (GOMES et al., 1989). **Based on IBGE (2011).

The data on damage caused by $D$. hominis larvae to cattle productivity were based on Magalhães and Lesskiu (1982), who found a yearly reduction in weight gain of $40.6 \mathrm{~g}$ per larva. The estimates of economic losses due to the cattle grub focused on regions where this parasite is abundant and important. Thus, average infestations on B. taurus (74 larvae/animal/year) and B. indicus (18.2 larvae/animal/year) were estimated for the central-western and southern regions, as well as for the state of Paraná, based on several studies (MAGALHÂES; LESSKIU, 1982; SARTOR, 1986; GOMES et al., 1988, 1996; CARNEIRO et al., 1990; OLIVEIRA, 1991; PINTO et al., 2002; FERNANDES et al., 2008; SOUZA et al., 2010). Considering that 19.12 million B. taurus and 90.96 million $B$. indicus are at risk, the potential losses in weight gain due to this parasite amount to $\$ 201.93$ million yearly.

The rate of damage to cattle hides caused by $D$. hominis larvae averaged $25.17 \%$ at slaughterhouses in the regions studied (BRITO; MOYA-BORJA, 2000; MARQUES et al., 2000; SANAVRIA et al., 2002), which represented annual losses of about $\$ 181.55$ million. Cattle hide damage caused by both cattle grubs and cattle ticks reached a rate of $40 \%$, as officially reported from a previous survey (BRASIL, 1983). Considering losses in relation to both weight gain and hide damage, the potential losses due to $D$. hominis larval infestation total $\$ 383.48$ million (Tables 4 and 5).

Occurrences of navel myiasis due to screwworm have been reported in $40.7 \%$ of calves in central-western Brazil 
Table 3. Economic losses due to the horn fly, Haematobia irritans, relating to beef cattle production in Brazil, in 2012.

\begin{tabular}{|c|c|c|c|c|c|}
\hline & Live animals at risk* & $\begin{array}{l}\text { Yearly weight } \\
\text { loss per head }\end{array}$ & $\begin{array}{l}\text { Total yearly } \\
\text { weight loss }\end{array}$ & Price to producer & Potential loss \\
\hline & (million head) & (kilogram) & $\begin{array}{l}\text { (millions of } \\
\text { kilograms) }\end{array}$ & (US\$/kilogram) & (millions of US\$) \\
\hline Steers/heifers & $113.09^{* *}$ & $\begin{array}{c}12.19 \\
\text { Bianchin et al. (2004) }\end{array}$ & $1,378.57$ & & $2,233.28$ \\
\hline Cows & $38.13^{* *}$ & $\begin{array}{c}3.25 \\
\text { Bianchin and Alves } \\
(2002)\end{array}$ & 123.92 & 1.62 & 200.75 \\
\hline Calves & $38.36^{* * *}$ & $\begin{array}{c}2.00 \\
\text { Bianchin and Alves } \\
(2002)\end{array}$ & 76.72 & CEPEA (2013a, b, c) & 124.29 \\
\hline & & & & Total potential loss & $2,558.32$ \\
\hline
\end{tabular}

${ }^{*}$ Considering population in December 2012. ${ }^{* *}$ Based on IBGE (2011) and Anualpec (INFORMA ECONOMICS FNP, 2013). ${ }^{* * *}$ Based on IBGE (2011) and Censo Agropecuário (IBGE, 2012).

Table 4. Economic losses due to the cattle grub, Dermatobia hominis, relating to beef cattle production in Brazil, in 2011.

\begin{tabular}{|c|c|c|c|c|c|c|}
\hline \multirow[t]{2}{*}{ Beef cattle } & $\begin{array}{c}\text { Population at } \\
\text { risk* }\end{array}$ & $\begin{array}{c}\text { Average number } \\
\text { of larvae per } \\
\text { animal }\end{array}$ & Weight loss & $\begin{array}{l}\text { Affected herd } \\
\text { yearly loss }\end{array}$ & Price to producer & Potential loss \\
\hline & (million head) & & (kg/larva/year) & $\begin{array}{l}\text { (millions of } \\
\text { kilograms) }\end{array}$ & (US\$/kilogram) & (millions of US\$) \\
\hline \multirow[t]{2}{*}{ Bos indicus } & 90.96 & 18.20 & 0.0406 & 67.21 & 1.62 & 108.88 \\
\hline & & $\begin{array}{l}\text { Fernandes et al. } \\
\qquad(2008)\end{array}$ & & & & \\
\hline \multirow[t]{2}{*}{ Bos taurus } & 19.12 & 74.00 & & 57.44 & & 93.05 \\
\hline & & $* *$ & $\begin{array}{l}\text { Magalhães and } \\
\text { Lesskiu (1982) }\end{array}$ & & $\begin{array}{c}\text { CEPEA } \\
(2013 \mathrm{a}, \mathrm{b}, \mathrm{c})\end{array}$ & \\
\hline
\end{tabular}

*Based on IBGE (2011). ** Carneiro et al. (1990), Gomes et al. (1988, 1996), Magalhães and Lesskiu (1982), Oliveira (1991), Pinto et al. (2002), Sartor (1986) and Souza et al. (2010).

Table 5. Economic losses due to the cattle grub, Dermatobia hominis, in the cowhide industry in Brazil, in 2012.

\begin{tabular}{|c|c|c|c|c|c|}
\hline \multirow[t]{2}{*}{ Cowhide } & $\begin{array}{c}\text { Yearly slaughtered } \\
\text { animals }\end{array}$ & Damaged hides* & Total damaged hides & $\begin{array}{c}\text { Raw cowhide value } \\
2012^{* *} \\
\end{array}$ & Potential loss \\
\hline & (million head) & $(\%)$ & (million) & (US\$ per hide) & (millions of US\$) \\
\hline \multirow[t]{3}{*}{ Beef cattle } & 19.55 & 25.17 & & 36.90 & \\
\hline & IBGE (2013) & & 4.92 & $\begin{array}{c}\text { Scot Consultoria, } \\
2013\end{array}$ & 181.55 \\
\hline & & & & $\begin{array}{l}\text { Total potential loss } \\
\text { (Tables } 4 \text { and } 5)\end{array}$ & 383.48 \\
\hline
\end{tabular}

*Estimates based on Brito and Moya-Borja (2000), Sanavria et al. (2002) and Marques et al. (2000); ${ }^{* *}$ Considering 45 kg of raw hide per animal.

(BIANCHIN et al., 1992), which is the main region for raising beef cattle in this country. Although endectocide products have been widely used to prevent and treat navel myiasis in newborn calves throughout Brazil, considerable losses persist. Barros et al. (2010b) reported a 5.5\% control failure rate for endectocide treatments against navel myiasis in calves, which was similar to the mortality rate $(5.32 \%)$ observed among 432 calves monitored until weaning (BIANCHIN et al., 1992). Considering a natural occurrence of $40.7 \%$ for screwworm attacks among calves and that $5.5 \%$ of treated animals may still develop myiasis, the losses due to potential calf mortality were estimated to be $\$ 310.55$ million (Table 6). Considering the population at risk to be just a small proportion of the calf population (i.e. only the animals presenting control failure and at risk of death), rather than the entire population of calves at potential risk of infestation, the estimated economic losses due to this parasite are probably closer to reality, but comparatively lower than those estimated for other parasite species. No estimate of the losses due to screwworm attacks among adult animals was possible, because of the lack of specific information, but this parasite and its economic implications certainly play an important role in several regions of this country.

The potential losses due to stable flies (S. calcitrans) were based on Kunz et al. (1991), who reported estimated losses of $100 \mathrm{~g}$ per steer per day in feedlots $(50 \%$ of the cattle were exposed to stable flies) and a $27 \mathrm{~kg}$ decrease in milk production per cow per year (stable flies were present for six months), in the USA. Considering that there are 4.08 million feedlot cattle in Brazil (ABIEC, 2013), the losses due to $S$. calcitrans were estimated as 
Table 6. Economic losses due to navel myiasis caused by the screwworm, Cochliomyia hominivorax, among calves in Brazil, in 2011.

\begin{tabular}{cccccc}
\hline & Population at risk* & $\begin{array}{c}\text { Prevalence of screw- } \\
\text { worm myiasis in } \\
\text { calves }\end{array}$ & $\begin{array}{c}\text { Failure of navel myia- } \\
\text { sis control in calves }\end{array}$ & $\begin{array}{c}\text { Average weaned calf } \\
\text { value }\end{array}$ & Potential loss \\
\cline { 2 - 6 } & (million head) & $\mathbf{( \% )}$ & $\mathbf{( \% )}$ & (US\$) & (millions of US\$) \\
\hline Calves & 41.58 & 40.7 & 5.5 & 361.66 & 336.62 \\
& Bianchin et al. (1992) & Barros et al. (2010b) & CEPEA \\
$(2013 \mathrm{a}, \mathrm{b}, \mathrm{c})$
\end{tabular}

${ }^{*}$ Considering calves born in 2011. Based on IBGE (2011) and Censo Agropecuário (IBGE, 2012).

Table 7. Economic losses due to the stable fly, Stomoxys calcitrans, among dairy and feedlot cattle in Brazil, in 2011/2012.

\begin{tabular}{|c|c|c|c|c|c|}
\hline & Population at risk & Milk loss & Total yearly loss & Price to producer & Potential loss \\
\hline & (million head) & (liter/cow/year) & (millions of liters) & (US\$/liter) & (millions of US\$) \\
\hline \multirow[t]{4}{*}{ Dairy cattle } & 23.23 & 27.00 & 627.21 & 0.44 & 275.97 \\
\hline & IBGE (2011) & Kunz et al. (1991) & & CEPEA (2013a, b, c) & \\
\hline & Population at risk & Loss at feedlots & Total loss at feedlots* & Price to producer & Potential loss \\
\hline & (million head) & (gram/head/day) & $\begin{array}{l}\text { (millions of } \\
\text { kilograms) }\end{array}$ & (US\$/kilogram) & (millions of US\$) \\
\hline \multirow[t]{3}{*}{ Feedlot cattle } & 4.08 & 100.00 & 36.72 & 1.62 & 59.49 \\
\hline & & Kunz et al. (1991) & & CEPEA (2013a, b, c) & \\
\hline & & & & Total potential loss & 335.46 \\
\hline
\end{tabular}

${ }^{*}$ Considering an average feedlot period of 90 days.

Table 8. Economic losses due to cattle parasitism in Brazil.

\begin{tabular}{lc}
\hline \multicolumn{1}{c}{ Parasite } & Millions of US\$ \\
\hline Gastrointestinal nematodes & $7,107.97$ \\
Cattle tick, Rhipicephalus (Boophilus) microplus & $3,236.35$ \\
Horn fly, Haematobia irritans & $2,558.32$ \\
Cattle grub, Dermatobia hominis & 383.48 \\
Screwworm fly, Cochliomyia hominivorax & 336.62 \\
Stable fly, Stomoxys calcitrans & 335.46 \\
Total potential loss & $\mathbf{1 3 , 9 5 8 . 2 0}$ \\
\hline
\end{tabular}

\$59.49 million (Table 7). Regarding milk production, the losses inflicted on dairy cattle were estimated as $\$ 275.97$ million. The total loss of $\$ 335.46$ million attributed to stable flies is probably an underestimate, since the impact of this pest on pastured cattle and the size of the affected population, particularly during severe outbreaks, is unknown and was not included here. In addition to the fact that losses during outbreaks are much higher than in regular infestations, it should be considered that the frequency and severity of these outbreaks in Brazil are increasing dramatically due to the rapid expansion of ethanol production from sugarcane. The present estimate of potential losses due to stable flies is much lower than the economic impact of $\$ 2,211$ million per year recently estimated for this pest among dairy and beef cattle in the USA (TAYLOR et al., 2012). Further investigations are needed regarding the current impact of stable flies on cattle production in Brazil.

Thus, the following economic losses, in millions of dollars, were estimated regarding the impact of these parasite species or groups for the respective cattle populations that were considered to be at risk: gastrointestinal nematodes $(\$ 7,107.97)$, cattle ticks $(\$ 3,236.35)$, horn flies $(\$ 2,558.32)$, cattle grubs $(\$ 383.48)$, screwworms (\$336.62) and stable flies (\$335.46).

The annual potential economic losses due to the five major ectoparasites and gastrointestinal worms of cattle in Brazil reach the impressive amount of $\$ 13.9$ billion (Table 8 ). This reflects the favorable environmental conditions for both livestock and their parasites in this country. The situation is aggravated by parasite control bottlenecks. When distributed across the national cattle herd (more than 212 million head), a yearly loss of $\$ 65.49$ per head was found, which might seem to be more tolerable. However, considering an average age at slaughter of 36 to 42 months, this yearly impact actually represents $32 \%$ of the beef cattle sale price (CEPEA, 2013a, b, c), thus making the potential damage due to cattle parasitism unacceptable for both producers and the cattle industry.

Regardless of the limitations of some of the baseline studies used to develop these estimates, particularly when extrapolated from local situations to a national scale, the general picture obtained from the present effort demonstrates the magnitude and importance of cattle parasitism in Brazil and the unfeasibility of a profitable livestock industry without proper parasite control.

Traditionally, chemicals have been used to manage parasites, with an impact on the wellbeing and health of domestic animals, including food-producing livestock (ECOBICHON, 2001; OLIVEIRA PASIANI et al., 2012). However, indiscriminate use of chemical pesticides for veterinary use has driven parasite populations to become resistant to many of them (ANDREOTTI et al., 2011; KAPLAN; VIDYASHANKAR, 2012; CASTRO JANER et al., 2012). Further studies assessing the contribution of pesticide resistance to the economic harm resulting from parasitic diseases in cattle are warranted.

Ultimately, establishment of a national program of parasite control and resistance management, as well as a solid extension program, will not only reduce the real impact of parasitism on the Brazilian cattle industry - taking it far from the potential damage currently estimated - but also enhance public and animal health. 


\section{References}

Andreotti R, Soares MA, Barros JC, Robert JM, Pérez de León A. Acaricide resistance of Rhipicephalus (Boophilus) microplus in State of Mato Grosso do Sul, Brazil. Rev Bras Parasitol Vet 2011; 20(2): 127-33. PMid:21722487. http://dx.doi.org/10.1590/S198429612011000200007

Associação Brasileira das Indústrias Exportadoras de Carne - ABIEC. 2013 [cited 2013 Apr 14]. Available from: http://www.abiec.com.br/ texto.asp?id=8.

Barros ATM, Koller WW, Catto JB, Soares CO. Surtos por Stomoxys calcitrans em gado de corte no Mato Grosso do Sul. Pesq Vet Bras 2010a; 30(11): 945-52. http://dx.doi.org/10.1590/S0100736X2010001100008

Barros ATM, Ravaglia E, Aquino WS, Passos W, Leite LTB. Eficácia de endectocidas em infestaçóes naturais por Cochliomyia hominivorax (moscavarejeira) em bezerros no Pantanal. Corumbá: Embrapa Pantanal; 2010b. 4 p. (Embrapa Pantanal. Circular Técnica, 90).

Bianchin I, Alves RGO. The hornfly, Haematobia irritans: behaviour and damage caused in Nellore cows and pre-weaning calves. Pesq Vet Bras 2002; 22(3): 109-13.

Bianchin I, Correa ES, Honer MR, Gomes A, Curvo JE. Uso de Ivermectin aplicado pela via subcutânea na prevenção de miíases umbilicais em bezerros de corte criados extensivamente. Rev Bras Parasitol Vet 1992; 1(2): 121-4.

Bianchin I, Honer MR, Nunes SG, Nascimento YA. Effect of stocking rates and anthelminthic treatments on weight gains in weaned Nellore cattle on improved pasture in the Brazilian cerrado. Trop Anim Health Prod 1995; 27(1): 1-8. PMid:7770946. http://dx.doi.org/10.1007/ BF02236326

Bianchin I, Koller WW, Alves RGO, Detmann E. Effects of the horn fly, Haematobia irritans (L.) (Diptera: Muscidae) in the weight gain on Nellore cattle. Cienc Rural 2004; 34(3): 885-90. http://dx.doi. org/10.1590/S0103-84782004000300035

Brasil. Ministério da Agricultura, Secretaria Nacional de Defesa Agropecuária, Secretaria de Defesa Sanitária Animal. Carrapato, berne e bicheira no Brasil. Brasília; 1983. 153 p.

Brito LG, Moya-Borja GE. Flutuação sazonal de Dermatobia hominis em peles bovinas oriundas de matadouro. Pesq Vet Bras 2000; 20(4):151-4. http://dx.doi.org/10.1590/S0100-736X2000000400004

Carneiro JR, Calil F, Oliveira CB. Variação estacional de larvas Dermatobia hominis (Diptera: Cuterebridae) em bovinos zebu x holandês da Bacia Leiteira de Goiânia. Rev Pat Trop 1990; 19(2): 121-6.

Castro Janer E, Sato Schumaker TT, Marcondes Klafke G, Rifran L, González P, Niell C, et al. Garrapata: resistencia a Fipronil e Ivermectina en rodeos vacunos de Uruguay y Brasil. Montevideo: INIA; 2012. 69 p. (Serie FTPA, n. 35).

Centro de Estudos Avançados em Economia Aplicada - CEPEA - ESALQ/ USP. Bezerro [online]. 2013a [cited 2013 Apr 14]. Available from: http:// cepea.esalq.usp.br/bezerro/.

Centro de Estudos Avançados em Economia Aplicada - CEPEA - ESALQ/ USP. Boi [online]. 2013b [cited 2013 Apr 14]. Available from: http:// cepea.esalq.usp.br/boi/.

Centro de Estudos Avançados em Economia Aplicada - CEPEA - ESALQ/ USP. Leite [online]. 2013c [cited 2013 Apr 14]. Available from: http:// cepea.esalq.usp.br/leite/.
Charlier J, Höglund J, Von Samson-Himmelstjerna G, Dorny P, Vercruysse J. Gastrointestinal nematode infections in adult dairy cattle: impact on production, diagnosis and control. Vet Parasitol 2009; 164(1): 70-9. PMid:19414223. http://dx.doi.org/10.1016/j.vetpar.2009.04.012

Drummond RO, Lambert G, Smally HE Jr, Terrill CE. Estimated losses of livestock to pests. In: Pimentel D. Handbook of pest management in agriculture. Boca Raton: CRC Press; 1981. p. 111-27. v.1.

Ecobichon DJ. Pesticide use in developing countries. Toxicology 2001; 160(1-3): 27-33. http://dx.doi.org/10.1016/S0300-483X(00)00452-2

Fernandes NLM, Thomaz-Soccol V, Pinto SB, Oliveira CAL. Dinâmica populacional e distribuição corporal das larvas de Dermatobia hominis (Linnaeus Jr., 1781) em bovinos da raça Nelore. Arch Vet Sci 2008; 13(2): 85-92.

Gomes A, Honer MR, da Silva RL. Intensidade parasitária de larvas de Dermatobia hominis (L. Jr. 1781) (Diptera: Cuterebridae) em bovinos de diferentes raças criadas extensivamente na regiáo de cerrado em Mato Grosso do Sul. Rev Bras Parasitol Vet 1996; 5(2): 103-6.

Gomes A, Honer MR, Schenk MA, Curvo JB. Populations of the cattle tick (Boophilus microplus) on purebred Nellore, Ibage and Nellore $\mathrm{X}$ European crossbreds in the Brazilian savanna. Trop Anim Health Prod 1989; 21(1): 20-4. PMid:2711457. http://dx.doi.org/10.1007/ BF02297336

Gomes A, Sousa JC, Resende AM, Curvo JBE. Distribuição corporal e sazonalidade do berne (larva de Dermatobia hominis) em bovinos tratados ou não com flor de enxofre. Pesq Agropec Bras 1988; 23(8): 825-9.

Grisi L, Massard CL, Moya Borja GE, Pereira JB. Impacto econômico das principais ectoparasitoses em bovinos no Brasil. Hora Vet 2002; 21(125): 8-10.

Horn SC. Prováveis prejuizos causados pelos carrapatos no Brasil. Brasília: Ministério da Agricultura, Secretaria Nacional de Defesa Agropecuária, Secretaria de Defesa Sanitária Animal; 1983. (Boletim de Defesa Sanitária Animal, n. especial).

Informa Economics FNP. ANUALPEC 2013: anuário da pecuária brasileira. 20th ed. São Paulo: Informa Economics FNP; 2013.

Instituto Brasileiro de Geografia e Estatística - IBGE. Censo Agropecuário 2006: Brasil, Grandes Regiōes e Unidades da Federação. 2. Apuração. Rio de Janeiro: IBGE; 2012. 774 p.

Instituto Brasileiro de Geografia e Estatística - IBGE. Indicadores IBGE: estatística da produção pecuária [online]. 2013. [cited 2013 Apr 14]. Available from: http://www.ibge.gov.br/home/estatistica/indicadores/ agropecuaria/producaoagropecuaria/abate-leite-couro-ovos_201301_ publ_completa.pdf.

Instituto Brasileiro de Geografia e Estatística - IBGE. Produção da Pecuária Municipal. Rio de Janeiro: IBGE; 2011. Available from: http:// www.ibge.gov.br/home/estatistica/economia/ppm/2011/default.shtm

Jonsson NN, Mayer DG. Estimation of the effects of buffalo fly (Haematobia irritans exigua) on the milk production of dairy cattle based on a meta-analysis of literature data. Med Vet Entomol 1999; 13(4): 372-6. http://dx.doi.org/10.1046/j.1365-2915.1999.00179.x

Jonsson NN. The productivity effects of cattle tick (Boophilus microplus) infestation on cattle, with particular reference to Bos indicus cattle and their crosses. Vet Parasitol 2006; 137(1-2): 1-10. PMid:16472920. http:// dx.doi.org/10.1016/j.vetpar.2006.01.010 
Kaplan RM, Vidyashankar AN. An inconvenient truth: global worming and anthelmintic resistance. Vet Parasitol 2012; 186(1-2): 70-8. PMid:22154968. http://dx.doi.org/10.1016/j.vetpar.2011.11.048

Kunz SE, Murrell KD, Lambert G, James LF, Terrill CE. Estimated losses of livestock to pests. In: Pimentel D. Handbook of pest management in agriculture. 2nd ed. Boca Raton: CRC Press; 1991. p. 69-98. v. 1.

Lima MM, Grisi L. Verminose subclínica em vacas em lactação no Estado do Rio de Janeiro. Hora Vet 1984; 19(4): 37-40.

Magalhães FEP, Lesskiu C. Efeito do controle do berne sobre o ganho de peso e qualidade dos couros em novilhos de corte. Pesqui Agropecu Bras 1982; 17(2): 329-36.

Marques FAC, Yamamura MH, Vidotto O. Lesôes no couro bovino causadas pelos principais ectoparasitas nas regióes Noroeste do Estado do Paraná e Sudoeste no Estado do Mato Grosso. Semina: Ci. Agrárias 2000; 21(1): 33-9.

National Agriculture Statistics Service - NASS, United States Department of Agriculture - USDA. Cattle inventory: executive briefing [online]. 2011 [cited 2013 Apr 14]. Available from: http://www.nass.usda.gov/ Newsroom/Executive_Briefings/2011/07_22_2011.pdf.

Oliveira GP. Epidemiologia de Dermatobia hominis (L. Jr. 1781) (Diptera: Cuterebridae) em bovinos na região de São Carlos, Estado de São Paulo. Braz J Vet Res Anim Sci 1991; 28(2): 179-84.

Oliveira Pasiani J, Torres P, Roniery Silva J, Diniz BZ, Caldas ED. Knowledge, attitudes, practices and biomonitoring of farmers and residents exposed to pesticides in Brazil. Int J Environ Res Public Health 2012; 9(9): 3051-68. PMid:23202670 PMCid:PMC3499853. http:// dx.doi.org/10.3390/ijerph9093051

Pinheiro AC. Programa integrado de controle de verminose de bovinos de corte. 2nd ed. Bagé: EMBRAPA-UEPAE de Bagé; 1983. 4 p. (EMBRAPAUEPAE de Bagé. Pesquisa em Andamento, 5).

Pinto SB, Soccol VT, Vendruscolo E, Rochadelli R, Ribeiro PB, Freitag A, et al. Bioecologia de Dermatobia hominis (Linnaeus Jr., 1781) em
Palotina, Paraná, Brasil. Cienc Rural 2002; 32(5): 821-7. http://dx.doi. org/10.1590/S0103-84782002000500013

Ploeger HW, Schoenmaker GJW, Kloosterman A, Borgsteede FHM. Effect of anthelmintic treatment of dairy cattle on milk production related to some parameters estimating nematode infection. Vet Parasitol 1989 34(3): 239-53. http://dx.doi.org/10.1016/0304-4017(89)90054-X

Rodrigues DS, Leite RC. Economic impact of Rhipicephalus (Boophilus) microplus: estimate of decreased milk production on a dairy farm. Arq Bras Med Vet Zootec 2013; 65(5): 1570-2. http://dx.doi.org/10.1590/ S0102-09352013000500039

Sanavria A, Barbosa CG, Bezerra ES, Morais MC, Giupponi PC. Distribuição e frequência de larvas de Dermatobia hominis (Linnaeus Jr., 1781) (Diptera: Cuterebridae) em peles de bovinos. Parasitol Latinoam 2002; 57(1-2): 21-4. http://dx.doi.org/10.4067/S071777122002000100006

Sartor AA. Parasitismo por larvas de Dermatobia hominis (Linnaeus, Jr., 1781), em bovinos no município de Lorena, Estado de Säo Paulo [Dissertação]. Rio de Janeiro: Universidade Federal Rural do Rio de Janeiro; 1986.

Smith RD, Evans DE, Martins JR, Ceresér VH, Correa BL, Petraccia C, et al. Babesiosis (Babesia bovis) stability in unstable environments. Ann NY Acad Sci 2000; 916: 510-20. PMid:11193666. http://dx.doi. org/10.1111/j.1749-6632.2000.tb05330.x

Souza FS, Botelho MCSN, Lisbôa RS. Caracterização de associação entre a sazonalidade de larvas de Dermatobia hominis em bovinos, dípteros potenciais vetores e dados meteorológicos de três diferentes locais no Rio de Janeiro. R Bras Cienc Vet 2010; 17(3-4): 111-6.

Taylor DB, Moon RD, Mark DR. Economic impact of stable flies (Diptera: Muscidae) on dairy and beef cattle production. J Med Entomol 2012; 49(1): 198-209. PMid:22308789. http://dx.doi.org/10.1603/ ME10050 